\title{
Fluorine F 18 alphaVbeta6-Binding Peptide
}

National Cancer Institute

\section{Source}

National Cancer Institute. Fluorine F18 alphaVbeta6-Binding Peptide. NCI Thesaurus.

Code C133094.

A radiotracer composed of a 20 amino acid peptide derived from the GH loop of an envelope protein (VP1) of the foot-and-mouth disease virus (FMDV), where the Nterminal lysine has been substituted with arginine, conjug ated with two polyethylene glycol units and radiolabeled with fluorine 18 , for potential positron emission tomography (PET) imaging of alphaVbeta6 integ rin expression. Upon administration, the arginineglycine-aspartic acid (RGD) motif within the peptide moiety of the fluorine $18 \mathrm{~F}$ alphaVbeta6-binding peptide selectively binds to alphaVbeta6 integrin. During PET imaging, alphaVbeta6-expressing tumor cells can be visualized and the degree of tumor growth can be determined. AlphaVbeta6 integ rin, a cell adhesion and signaling receptor, is upregulated in certain cancers and has been associated with proliferation, migration and invasion of tumor cells. 